An official journal of the / Un journal officiel de la "Société Sénégalaise de Cancérologie" (SOSECAN)

Journal homepage: www.africanjournalofoncology.com

Review / Synthèse

DOI: https://www.doi.org/I0.54266/ajo. I.2.42.PPTT9|23

\title{
Breast reconstruction after breast cancer
}

\section{Reconstruction mammaire pour cancer du sein}

\author{
ME. Charfi", S. Ka', A. Dem'. \\ ' Institut Joliot Curie, Dakar, Sénégal.
}

\section{INTRODUCTION}

With an incidence of 47.8 per 100,000 populations, breast cancer is the most common cancer in terms of incidence worldwide in 2020 [I]. In most cases, its treatment involves breast surgery. This surgery can be radical in some cases [2]. This surgery is a mastectomy with axillary dissection or sentinel lymph node biopsy. However, patient satisfaction is not limited to the treatment of the disease but also to the aesthetic aspects of these treatments. Thus, these women are asking for breast reconstruction (BR) which can be instantaneous or delayed. In this review, we have tried to take stock of the different aspects of BR.

\section{BREAST RECONSTRUCTION IN ONCOLOGY}

BR after mastectomy is a breast surgery whose main goal is to improve the psychosocial outcome of the patient. From the announcement of the diagnosis, through systemic treatments, surgery amplifies psychological morbidity [3, 4]. Reconstruction is a functional treatment that has no impact on survival. It should not modify a therapeutic strategy in oncology [5-7]. Several techniques have been developed in recent years. However, there is no consensus on the indications for the different reconstructions. Patient satisfaction is associated with their clinical and cosmetic outcomes [3, 8-II]. However, in general, BR after mastectomy is associated with qualitatively comparable benefits to those observed after breast-conserving surgery [12, 13]. The BR technique varies depending on the technique used. It can be performed either with an internal breast prosthesis or with an autologous flap and its timing varies depending on whether it is performed immediately after the mastectomy (IBR) during the same procedure or delayed (DBR).

\section{BREAST RECONSTRUCTION WITH INTERNAL PROTHESIS}

$\mathrm{BR}$ with internal prosthesis is based on the principle of placing a prosthesis in the retro-pectoral space. This is a relatively simple process; however, skin coverage is the main limitation. It can be immediate or delayed, with or without a flap, with or without progressive tissue expansion [14]. In some cases, a skin preparation is necessary to prepare for the expansion of skin tissue by the underlying prosthesis. On the other hand, this is not the only limit to this type of construction. The other difficulty is breast volume. Indeed, the prostheses placed are generally small and an asymmetry of volume can be noted with the contralateral breast which will require a symmetrization gesture which is necessary in 20 to $60 \%$ of cases [15]. However, postponing the placement of the prosthesis allows a better assessment of the cosmetic result. However, this surgery is not without its risks. The main complications are hematomas, collections, infections, skin necrosis, exposures, perforations, prosthesis dislocations and especially prosthesis retractions. The latter is the main cause of failure of internal prosthetic BR [16]. The risk factors are postoperative hematomas, local sepsis and the subcutaneous positioning of the prosthesis [17]. Therefore, it is recommended to perform rigorous surgical hemostasis, perioperative prophylaxis, the use of acellular matrix and retro-pectoral positioning. The surface of the prosthesis and the filling material have no role in prosthetic retraction. The role of radiotherapy is controversial $[18,19]$.

\section{BREAST RECONSTRUCTION \\ AUTOLOGOUS FLAP}

Given the limits of BR by internal prosthesis, new procedures have emerged. It is autologous flap BR. Several techniques using different flaps have been described [13]. Two main flaps are used: the latissimus dorsi musculocutaneous flap (LDMF) and the transverse rectus abdominis musculocutaneous flap (TRAMF). Regardless of the technique used, the complications of this type of BR are independent of the type of flap and can affect the donor site as the reconstructed site. At the donor site, these are hematomas, collections, chronic pain or paresis. At the reconstructed site, these are ischemic fatty necrosis, skin necrosis, infections, collections or extensive flap necrosis generally requiring a second flap $[6,20]$.

The LDMF is relatively simple and quick to implement. Usually, there are no functional complications associated with the mobilization of this flap. The only limitation on the use of this flap is the stifle of the tissue mobilized. Thus, this flap should be reserved for small BR or in combination with an internal prosthesis. In the latter case, it should be noted that the complications of the two procedures add up without reducing the incidence of prosthetic contractions [3, 21, 22].

The TRAMF offers more possibilities despite being more complex to implement. It allows a large amount of tissue to be mobilized. Thus, it is recommended in large volume BR or in the case of large skin excision. The transversa suprapubic scar is generally better accepted by patients. However, this procedure is associated with a greater risk of bleeding and 
exposes the walls to complications that are sometimes disabling [23]. The main risk factors are the experience of the surgeon, obesity, smoking, history of laparotomy and adjuvant radiotherapy [24].

Whatever the type of flap used, the associated complications are comparable, varying between 10 and 54\%. Partial necrosis, the main complication of flaps, occurs in 0-21.5\% [3].

\section{IMMEDIATE OR DELAYED BREAST RECONSTRUCTION}

Historically, the first BR were performed on women seeking mastectomy at a distance of the first surgery. However, this trend has evolved and women are starting to request immediate $B R$ at the same time as mastectomy: IBR have a better psychological outcome than DBR. Despite this, surgeons prefer DBR over IBR because of the advantages of functional treatment (curative then maintenance) and also allowing the patient to better decide on the type of BR and to better choose [3]. On the other hand, from a psychological point of view, this interval allows the woman to mourn the breast and to better accept her new body image in the long term [25]. On a practical level, an DBR makes it possible to organize better logistically and adapt the BR technique to local conditions following curative treatments [3]. In the absence of external radiotherapy (ERT), the different $B R$ techniques are comparable and satisfactory. However, a history of ERT makes it necessary to adapt the BR technique to the extent of postradiation lesions of the integuments of the chest wall [3].

\section{EXTERNAL RADIOTHERAPY AND BREAST RECONSTRUCTION}

The ERT can be carried out before the BR. The loss of vitality and elasticity of the tissues after this ERT explain the poor results of BR with internal prosthesis. Indeed, the failure rate reaches $80 \%$ [26]. Among the complications, we cite painful expansions, defective projection of the breast volume, impressions and fractures of the ribs [3]. Unlike prosthetic BR, flap BR provide good results after ERT. This effectiveness is explained by the possibility of replacing radiation tissue with healthy non-irradiated tissue. Indeed, TRAMF is associated with excellent results, especially when local conditions are the most unfavorable [3, 27].

However, ERT can be performed after BR. This BR, old or recent, prosthetic or flap, does not interfere with the effectiveness of ERT. It is the aesthetic complications that come to the fore [3]. In the case of an old BR, the results are satisfactory but the aesthetic complications are poorly understood [3]. The most frequent case is an adjuvant ERT after an IBR. This ERT has no impact on the scar, but many studies conclude that it has a negative effect. In fact, the complications and in particular the capsular retractions of internal prostheses seem to be increased [28]. The complication rate can reach $48 \%$, including $15 \%$ capsular retractions [3]. For BR with flap, the published results are contradictory [3].

\section{CONCLUSION}

The psychological effect on women after mastectomy in most cases dictates the performance of BR. Several techniques exist and the timing of these BR is variable. However, a case-by-case assessment makes it possible to best judge the technique and the timing.

\section{CONFLICTS OF INTEREST}

The authors have declared no conflict of interest.

\section{REFERENCES}

I. Cancer Today [Internet]. Cancer Today. 202I [cited I 3 July 202I]. Available from: https://gco.iarc.fr/today/

2. Lembrouck C, Nicolet G, Nguyen A, Tunon de Lara C. État des lieux de la reconstruction mammaire après cancer du sein sur l'île de la Réunion en 2016. Gynécologie Obstétrique Fertilité \& Sénologie. 2019;47(3):297-304.

3. Ananian $P$, Protière $C$, Tallet $A$, Arnaud S, JulianReynier C, Houvenaeghel G. Reconstructions mammaires après mastectomie pour cancer du sein : quelles indications retenir ?. Annales de Chirurgie. 2004;129(4): 192-202.

4. Krueger E, Wilkins E, Strawderman M, Cederna P, Goldfarb S, Vicini F et al. Complications and patient satisfaction following expander/implant breast reconstruction with and without radiotherapy. Intern J Rad Oncol Biol Phys. 200I;49(3):7I3-72I.

5. O'Brien W, Hasselgren P, Hummel R, Coith R, Hyams $D$, Kurtzman $L$ et al. Comparison of postoperative wound complications and early cancer recurrence between patients undergoing mastectomy with or without immediate breast reconstruction. The American Journal of Surgery. 1993; 166(1): I-5.

6. Eberlein T, Crespo L, Smith B, Hergrueter C, Douville L, Eriksson E. Prospective Evaluation of Immediate Reconstruction After Mastectomy. Annals of Surgery. 1993;218(I):29-36.

7. Morrow M. Factors influencing the use of breast reconstruction postmastectomy: a national cancer database study. Journal of the American College of Surgeons. 200I;192(1): I-8.

8. Arora N, Gustafson D, Hawkins R, McTavish F, Cella $D$, Pingree $S$ et al. Impact of surgery and chemotherapy on the quality of life of younger women with breast carcinoma. Cancer. 2001;92(5): I 288-1298.

9. Pandey M, Singh S, Behere P, Roy S, Singh S, Shukla V. Quality of life in patients with early and advanced carcinoma of the breast. European Journal of Surgical Oncology (EJSO). 2000;26(I):20-24.

10. Schover L, Yetman R, Tuason L, Meisler E, Esselstyn C, Hermann R et al. Partial mastectomy and breast reconstruction. A comparison of their effects on psychosocial adjustment, body image, and sexuality. Cancer. 1995;75(I):54-64.

II. Fallowfield LJ. Psychosocial adjustment after treatment for early breast cancer. Oncology (Williston Park). 1990 Apr;4(4):89-97.

12. Al-Ghazal S, Fallowfield L, Blamey R. Comparison of psychological aspects and patient satisfaction following breast conserving surgery, simple mastectomy and breast reconstruction. European Journal of Cancer. 2000;36(I 5):1938-1943.

13. Harcourt D, Rumsey N. Psychological aspects of breast reconstruction: a review of the literature. Journal of Advanced Nursing. 200 I;35(4):477-487. 
14. Radovan C. Breast Reconstruction after Mastectomy Using the Temporary Expander. Plastic and Reconstructive Surgery. 1982;69(2): 195-206.

I5. Sandelin K, Billgren A, Wickman M. Management, morbidity, and oncologic aspects in 100 consecutive patients with immediate breast reconstruction. Annals of Surgical Oncology. I998;5(2): I59-I65.

16. Schuster RH, Kuske RR, Young VL, Fineberg B. Breast reconstruction in women treated with radiation therapy for breast cancer: cosmesis, complications, and tumor control. Plast Reconstr Surg. 1992;90(3):445-52;

17. Yun J, Diaz R, Orman A. Breast Reconstruction and Radiation Therapy. Cancer Control. 2018;25(I): I0732748/879548.

18. Embrey M, Adams E, Cunningham B, Peters W, Young V, Carlo G. A Review of the Literature on the Etiology of Capsular Contracture and a Pilot Study to Determine the Outcome of Capsular Contracture Interventions. Aesthetic Plastic Surgery. 1999;23(3):197-206.

19. Spear S, Onyewu C. Staged Breast Reconstruction with Saline-Filled Implants in the Irradiated Breast: Recent Trends and Therapeutic Implications. Plastic \& Reconstructive Surgery. 2000; 105(3):930-942.

20. Yeh KA, Lyle G, Wei JP, Sherry R. Immediate breast reconstruction in breast cancer: morbidity and outcome. Am Surg. 1998;64(I2): I 195-9.

21. Faucher $A$, Génin Etcheberry $T$, Picot $V$. Reconstruction mammaire après cancer du sein. Bilan d'une expérience de 12 années [Breast reconstruction after breast cancer: a review of a 12 year-long experience]. Ann Chir Plast Esthet. 1997;42(2): I 10-7.

22. Noguchi $M$, Fukushima $W$, Ohta $N$, Koyasaki $N$, Thomas M, Miyazaki I et al. Oncological aspect of immediate breast reconstruction in mastectomy patients. Journal of Surgical Oncology. 1992;50(4):24I-246.

23. Yeh KA, Lyle G, Wei JP, Sherry R. Immediate breast reconstruction in breast cancer: morbidity and outcome. Am Surg. 1998;64(I2): I 195-9.

24. Gulyás $G$. Az emlödaganatok mütéteinek plasztikai sebészeti vonatkozásai. Emlö-helyreállító mütétek saját szövetek felhasználásával [Plastic surgery in the context of surgery for breast cancer. Breast reconstruction using the patient's own tissue]. Orv Hetil. 1995; 136(3): 123-7.

25. Parkes C. Components of the reaction to loss of a limb, spouse or home. Journal of Psychosomatic Research. 1972;16(5):343-349.

26. Collis N, Coleman D, Foo I, Sharpe D. Ten-Year Review of a Prospective Randomized Controlled Trial of Textured versus Smooth Subglandular Silicone Gel Breast Implants. Plastic and Reconstructive Surgery. 2000;106(4):786-79I.

27. Tran N, Chang D, Gupta A, Kroll S, Robb G. Comparison of Immediate and Delayed Free TRAM Flap Breast Reconstruction in Patients Receiving Postmastectomy Radiation Therapy. Plastic and Reconstructive Surgery. 200I;108(I):78-82.
28. Evans GR, Schusterman MA, Kroll SS, Miller MJ, Reece GP, Robb GL, Ainslie N. Reconstruction and the radiated breast: is there a role for implants? Plast Reconstr Surg. 1995;96(5): I I I I-5. 